\title{
PERTUMBUHAN IKAN BETOK (Anabas testudineus Bloch) DI BERBAGAI HABITAT DI LINGKUNGAN DANAU MELINTANG - KALIMANTAN TIMUR
}

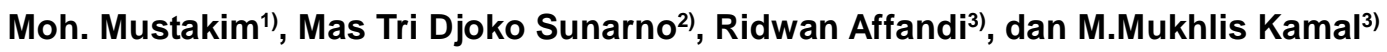 \\ 1) Dosen Fakultas Fakultas Perikanan dan IImu Kelautan, Universitas Mulawarman, Banjarmasin, \\ 2) Peneliti pada Pusat Riset Perikanan Tangkap \\ 3) Dosen pada Fakultas Perikanan dan IImu Kelautan IPB \\ Teregistrasi I tanggal: 5 Pebruari 2009; Diterima setelah perbaikan tanggal: 6 April 2009; \\ Disetujui terbit tanggal: 1 Mei 2009
}

\begin{abstract}
ABSTRAK
Tujuan dari penelitian ini adalah untuk mengetahui pertumbuhan ikan betok di berbagai habitat di lingkungan Danau Melintang Kalimantan Timur. Penelitian ini dilakukan dengan metode survei selama musim penghujan, yaitu bulan November 2007 hingga Januari 2008. Stasiun pengamatan ditetapkan secara sengaja di perairan danau, sungai dan rawa banjiran (flood plain). Di setiap stasiun pengamatan tersebut, ikan betok (Anabas testudinus) ditangkap dengan alat tangkul, jaring insang dan keblat. Ikan contoh dihitung dan masing-masing diukur panjang total dan bobotnya. Hubungan panjang berat dan pendugaan pertumbuhan ikan betok di masing-masing habitat diamati. Hasil penelitian menunjukkan bahwa hasil tangkapan ikan betok terbanyak di rawa. Pola pertumbuhan ikan betok jantan dan betina di habitat rawa berbeda, masing-masing mengikuti pola isometrik dan alometrik. Pola pertumbuhan ikan tersebut di sungai dan danau adalah alometrik, baik jantan maupun betina. Berdasarkan atas dugaan parameter pertumbuhan Von Bertalanffy, nilai $\mathrm{K}$ dan $\mathrm{L}_{\text {" }}$ untuk ikan betok adalah $0,73 \mathrm{th}^{-1}$ dan $214,2 \mathrm{~mm}$ di rawa, 0,66 th-1 dan $204,23 \mathrm{~mm}$ di sungai dan $1,30 \mathrm{th}^{-1}$ dan $200,55 \mathrm{~mm}$ di danau.
\end{abstract}

KATAKUNCI: $\quad$ betok, Anabas testudienus, habitat, Lingkungan Danau Melintang

ABSTRACT: $\quad$ Growth of climbing perch (Anabas testudineus Bloch) in different habitats of Lake Melintang Area, East Kalimantan Province, By Moh. Mustakim, Mas Tri Djoko Sunarno, Ridwan Affandi, and M.Mukhlis Kamal

This research proposed to observe growth pattern of climbing perch (Anabas testudineus) in different habitats of Lake Melintang area, East Kalimantan Provincy. The research was executed using survey methods during rainy season, namely from November 2007 to January 2008. Sampling station was defined purposively in body of lake, river and floodplain area, respectively. In each station, the climbing perch was caught using lift net, gill net and trap (keblat). The fishes were numbered and measured for their total length and weight individually. Lenght and weight relationship and estimation of fish growth were calculated. The results indicated that the highest number of the climbing perch was observed in floodplain. Differences of growth pattern were observed for male and female of the fishes caught in floodplain, namely isometric and allometric respectively. However, there was no differences of the growth pattern in lake and river, following allometric growth. Base on von Bertalanffy equation, the values of $K$ and $L$, for climbing perch were $0.73 \mathrm{yr}^{1}$ and $214.2 \mathrm{~mm}$; 0,66 $\mathrm{yr}^{1}$ and 204,23 $\mathrm{mm}$ and 1,30 $\mathrm{yr}^{-1}$ and 200,55 $\mathrm{mm}$ for floodplain, river and lake, respectively.

KEYWORDS: $\quad$ climbing perch, Anabas testudineus, habitat, Lake Melintang

\section{PENDAHULUAN}

Pertumbuhan ikan merupakan fungsi dari input makanan yang diterima dan kesuaian lingkungan hidupnya. Sepanjang lingkungan perairan sesuai dengan kebutuhan ikan, pertumbuhan ikan akan dibatasi oleh sediaan makanan. Ikan mempunyai naluri untuk memilih makanan sesuai dengan kebutuhannya secara efisien.

Ikan akan cenderung mencari makan dengan menginvestasikan energinya secara efisien. Sediaan makanan untuk ikan berbeda di berbagai ekosistem danau, sungai dan rawa, khususnya antara musim kemarau dan penghujan. Pada saat permukaan air menggenangi wilayah sekitar perairan, bahan organik (serasah) akan diuraikan oleh bakterial dan jamur. Serasah ini kemudian akan terbawa arus air ke bagian hilir dan mengendap di bagian air yang dalam (danau, sungai dan rawa yang mempunyai lebung). Proses dekomposisi bahan organik ini merupakan pasokan nutrien untuk proses sintesis (gelap dan terang) dan rantai makanan awal di suatu perairan. 
Di sisi lain, proses dekomposisi bahan organik akan menghasilkan penurunan $\mathrm{pH}$ dan kandungan oksigen terlarut serta peningkatan kandungan karbon dioksida bebas dan amonia-N. Kondisi demikian mendorong berbagai jenis ikan untuk bermigrasi menuju lingkungan perairan yang lebih baik, kecuali kelompok ikan kehitaman (black fish) yang mempunyai alat pernafasan tambahan, antara lain ikan betok atau papuyu (Anabas testudineus Bloch). Artinya, ikan betok dapat hidup di lingkungan danau, rawa dan sungai.

Di sisi lain, ikan, termasuk ikan betok, akan menginvenstasikan enerjinya secara efisien untuk mencari makan sesuai dengan kesukaannya (food habit). Kebiasaan makanan ini berbeda, bergantung antara lain kepada ukuran dan kondisi fisiologisnya. Ikan betok dewasa tergolong jenis ikan omnivora yang cenderung karnivora.

Serasah yang banyak terdapat di daratan akan terbawa oleh arus air selama musim penghujan. Serasah ini dapat dimanfaatkan secara langsung oleh ikan dan merupakan input nutrien bagi fitoplankton. Sediaan sumber makanan ini berbeda di setiap ekosistim perairan. Perairan berarus deras cenderung mempunyai sediaan makanan relatif sedikit dibandingkan perairan berarus kurang deras. Hal ini dicirikan oleh kelimpahan ikan di setiap tipe perairan tersebut.

Ikan betok atau papuyu merupakan salah satu jenis ikan air tawar yang umum ditemukan di rawa, sawah, dan parit-parit serta kolam-kolam yang mendapatkan luapan air atau berhubungan dengan saluran air terbuka. Ikan ini mempunyai nilai ekonomis relatif tinggi dan disukai di Kalimantan. Kondisi ini menyebabkan permintaan masyarakat terhadap ikan tersebut relatif tinggi dan cenderung terus meningkat dengan pertambahan penduduk. Hingga saat ini, pemenuhan permintaan pasar akan ikan tersebut masih sepenuhnya bergantung kepada hasil tangkapan di alam karena budidaya ikan betok masih belum intensif dilakukan. Ikan betok yang ditangkap umumnya berukuran besar dan bahkan dalam kondisi matang gonad.

Peningkatan kegiatan penangkapan ikan diduga menyebabkan penurunan populasinya. Tambahan, penggunaan alat tangkap yang tidak ramah lingkungan seperti keblat dan perubahan kondisi lingkungan seperti meningkatnya kekeruhan (Pollnac \& Malvestuto, 1992) mempunya andil dan pengaruh terhadap kelangsungan hidup ikan-ikan di daerah tersebut. Oleh karena itu, suatu upaya penyelamatan populasi ikan betok perlu dilakukan antara lain melalui pengumpulan data pertumbuhan dan habitat yang disukai oleh ikan tersebut.

Lingkungan Danau Melintang, Kabupaten Kutai Kertanegara, Provinsi Kalimantan Timur mempunyai tipe habitat sungai, rawa dan danau. Pada saat musim kemarau, permukaan air menyurut, ketiga habitat tersebut terpisah dan sebaliknya pada musim penghujan, permukaan air menyatu - air meluap menggenangi daerah paparan danau, rawa, genangan dan alur-alur sungai. Kondisi ini mengakibatkan beragamnya habitat yang tersedia bagi organisme akuatik (Welcomme, 1985). Besarnya keragaman habitat di kawasan tersebut mempunyai peranan penting bagi ikan untuk mencari makan, berkembangbiak dan pengasuhan anak-anak ikan, termasuk betok.

Penelitian dilaksanakan dengan tujuan untuk mengetahui distribusi hasil tangkapan dan pertumbuhan ikan betok di lingkungan Danau Melintang Kalimantan Timur.

\section{BAHAN DAN METODE}

Penelitian ini dilaksanakan selama 3 (tiga) bulan mulai bulan Nopember 2007 hingga Januari 2008. Lokasi penelitian adalah di perairan Daerah Mahakam Tengah khususnya lingkungan Danau Melintang. Analisis sampel ikan dilakukan di Laboratorium Ekobiologi Fakultas Perikanan dan IImu Kelautan Institut Pertanian Bogor.

Ikan betok (Anabas testudineus) diambil dari stasiun yang ditetapkan secara sengaja di berbagai tipe perairan yang merupakan habitat ikan tersebut, yaitu rawa banjiran, sungai dan danau (Gambar 1). Habitat rawa (Stasiun I) memiliki karakteristik seperti kerapatan tanaman air yang tinggi, warna air jernih kehitaman, kedalaman air relatif dangkal dan airnya stagnan. Habitat sungai (Stasiun II) dicirikan dengan adanya aliran air, dan warna air keruh dan habitat danau (Stasiun III) memiliki ciri-ciri dengan airnya yang stagnan dan warna air mirip dengan habitat sungai.

Penangkapan ikan contoh dilakukan setiap bulan di setiap stasiun pengamatan dengan menggunakan alat tangkap yang dipergunakan oleh nelayan setempat, yaitu jaring insang (gill net) bermata jaring satu inch, keblat (trap) dan tangkul (lift net). Keblat dioperasikan di habitat rawa yang dipasang pada daerah-daerah yang agak terbuka selama satu hari satu malam. Tangkul dioperasikan di habitat sungai dengan umpan sisa makanan dan potongan daging ikan. Jaring insang dipasang di habitat danau pada waktu sore hari dan diangkat pada waktu pagi harinya. 


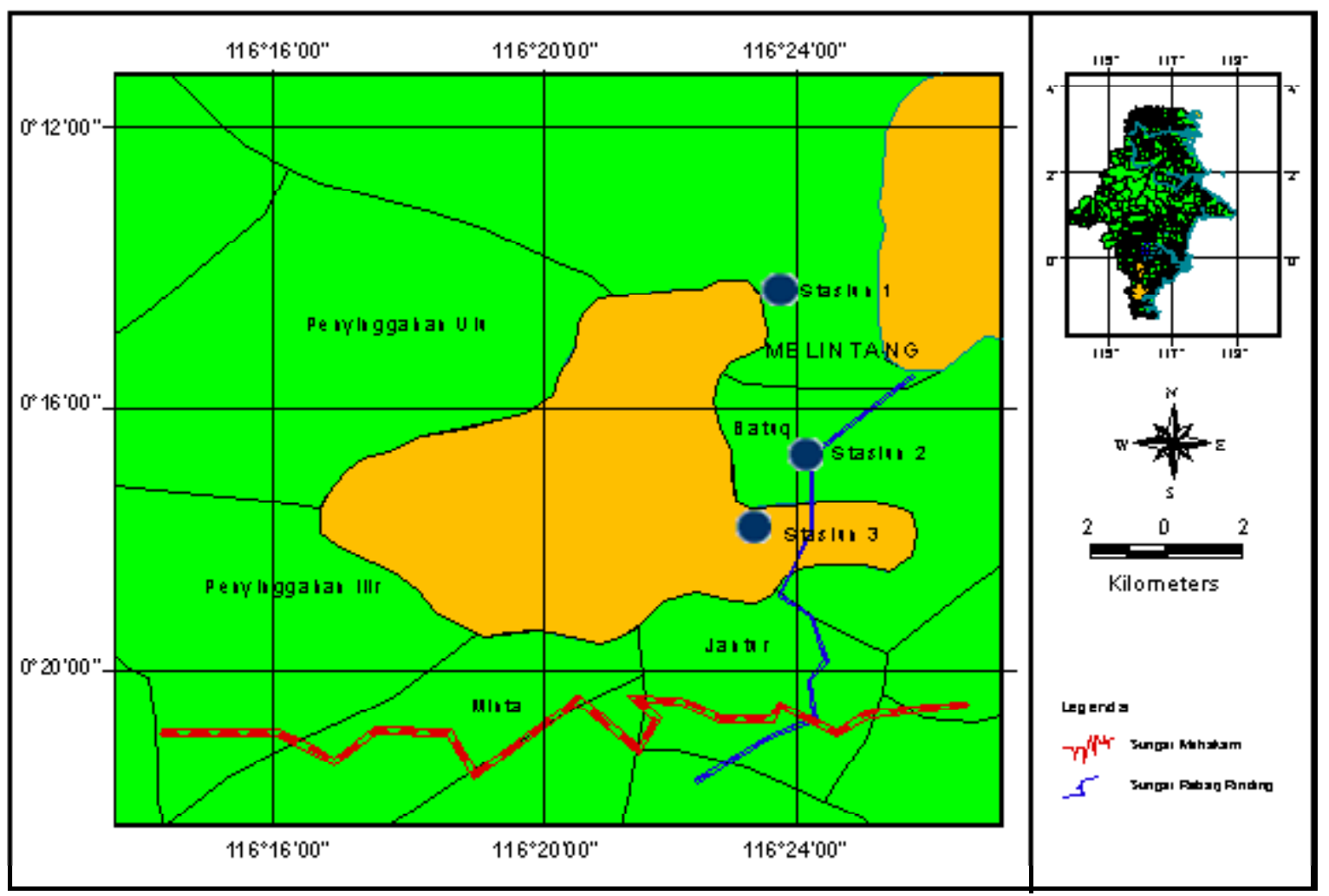

Gambar 1. Peta lokasi penelitian ikan betok (A. testudineus) di kawasan Danau Melintang, Kalimantan Timur

Figure 1. Map of research location of climbing perch (A. testudineus) in Lake Melintang area of East Kalimantan

Ikan hasil tangkapan dipisahkan berdasarkan habitat pengamatan. Ikan contoh diambil secara acak, mulai yang terkecil sampai terbesar sekurangkurangnya $10 \%$ dari total hasil tangkapan. Ikan contoh tersebut dimasukan ke dalam kantong plastik berisi formalin $10 \%$ yang diberi label untuk diamati di laboratorium. Pengukuran panjang total dan bobot ikan menggunakan papan ukur dengan ketelitian $0,01 \mathrm{~mm}$ dan timbangan dengan ketelitian 0,01 gram.

Analisis hubungan panjang berat menggunakan uji regresi, dengan rumus sebagai berikut (Effendie, 1979):

$\mathrm{W}=\mathrm{aL}^{b}$ di mana:

$$
\begin{array}{ll}
\mathrm{W} & =\text { Berat tubuh ikan }(\mathrm{g}) \\
\mathrm{L} & =\text { Panjang ikan }(\mathrm{mm})
\end{array}
$$$$
\mathrm{a} \text { dan } \mathrm{b}=\text { konstanta }
$$

Uji t dilakukan terhadap nilałb untuk mengetahui apakah $b=3$ (isomertik) atau $b=3$ (alometrik).

Pertumbuhan panjang ikan dapat dihitung dengan Model Von Bertalanffy sebagai berikut (Sparre \& Venema, 1999).

$$
\mathrm{L}_{\mathrm{t}}=\mathrm{L}_{\infty}\left(1-\mathrm{e}^{-\mathrm{K}(\mathrm{t}+\mathrm{to})}\right.
$$

di mana:

$L_{t} \quad$ = panjang ikan pada umur ke-t $(\mathrm{mm})$

$\mathrm{L}_{\infty} \quad=$ panjang maksimal $(\mathrm{mm})$

$\mathrm{K}=$ koefisien pertumbuhan $\left(\mathrm{t}^{-1}\right)$

$\mathrm{t}_{0} \quad=$ umur hipotesis ikan pada panjang nol (tahun)

Nilai $L_{\text {„ dan }} \mathrm{K}$ didapatkan dari hasil penghitungan dengan metode ELEFAN 1 yang terdapat dalam program FiSAT II.

Nilai $t_{0}$ dapat diduga dengan persamaan berikut (Utomo, 2002).

$$
\log -\left(t_{0}\right)=-0,3922-0,2752 \log L_{n}-1,03 \log K \ldots(3
$$

\section{HASIL DAN BAHASAN}

\section{Distribusi Hasil Tangkapan}

Jumlah ikan betok yang dikumpulkan selama penelitian di tiga habitat adalah 431 ekor. Hasil tangkapan terbesar berasal dari habitat rawa sebanyak 
216 ekor yang terdiri atas 128 jantan dan 88 betina, sedangkan dari sungai diperoleh 80 ekor dengan perbandingan hasil tangkapan seimbang selama penelitian, yakni 40 jantan dan 40 betina, dan dari danau didapatkan 135 ekor dengan komposisi 72 jantan dan 63 betina (Gambar 2).

Distribusi hasil tangkapan terbanyak secara berurutan ditemukan di habitat rawa, kemudian danau dan terakhir sungai. Hal ini diduga karena habitat tersebut memiliki kerapatan vegetasi yang berbedabeda, yaitu habitat rawa memiliki kerapatan tanaman air yang tinggi dibandingkan sungai dan danau. Kenyataan ini diperkuat oleh analisis regresi antara persentase kerapatan tanaman air dengan kelimpahan hasil tangkapan. Hasil analisis regresi tersebut menunjukkan bahwa adanya korelasi positif ( $r=$ $0,9555)$, berarti terdapat hubungan yang sangat erat antara kerapatan tanaman air dengan hasil tangkapan (Gambar 3). Kelimpahan populasi ikan dengan kerapatan tanaman air juga ditemui pada ikan Telmatherina ladigesi di Danau Towuti Sulawesi Selatan yang mempunyai korelasi positif atau keeratan hubungan yang cukup signifikan terutama pada waktu melakukan pemijahan (Nasution, 2000).

Distribusi ikan dipengaruhi oleh beberapa faktor. Krebs (1985) menyatakan bahwa distribusi ikan dipengaruhi oleh tingkah laku ikan dalam memilih habitat dan hubungan antara ikan tersebut dengan organisme lain. Demikian pula halnya dengan ikan betok. Penczak (1995) menyatakan, fluktuasi kelimpahan ikan yang berhubungan dengan keberadaan tanaman air juga ditemui di Sungai Warta Polandia. Indikasinya adalah menurunnya hasil tangkapan ikan jenis phytophil, lithophil, psamophil, pelagophil, dan jenis lain seperti belut, yang dikaitkan dengan hilangnya jenis-jenis tanaman termasuk akarakar yang tenggelam di sungai tersebut.

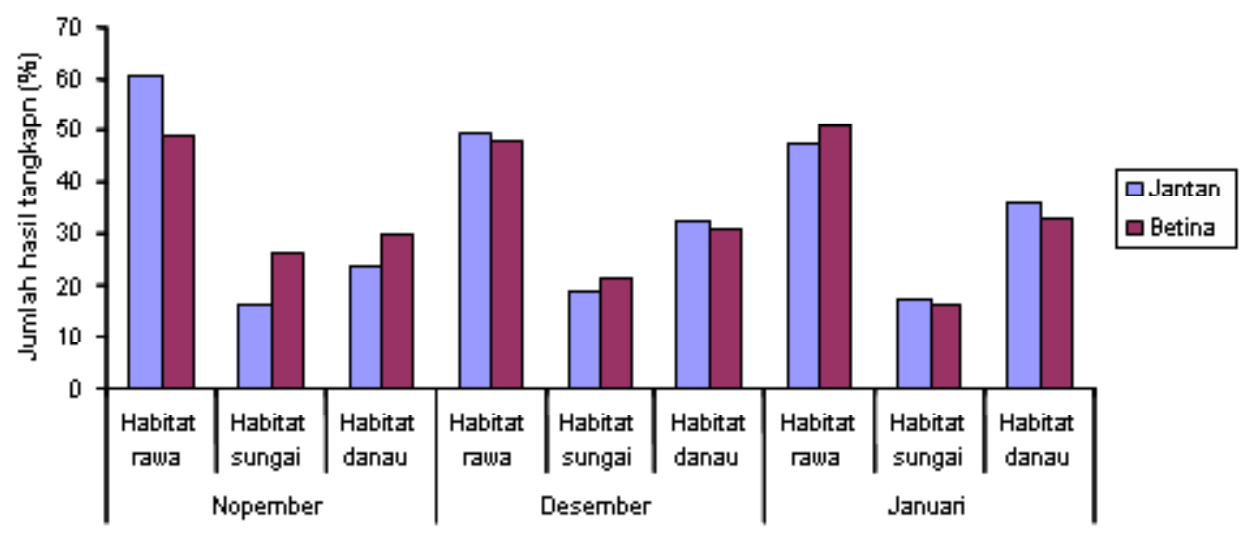

Gambar 2. Distribusi hasil tangkapan ikan betok ( $A$. testudineus) di setiap habitat selama penelitian. Figure 2. Catch distribution of climbing perch (A. testudineus) in each habitat during observation.

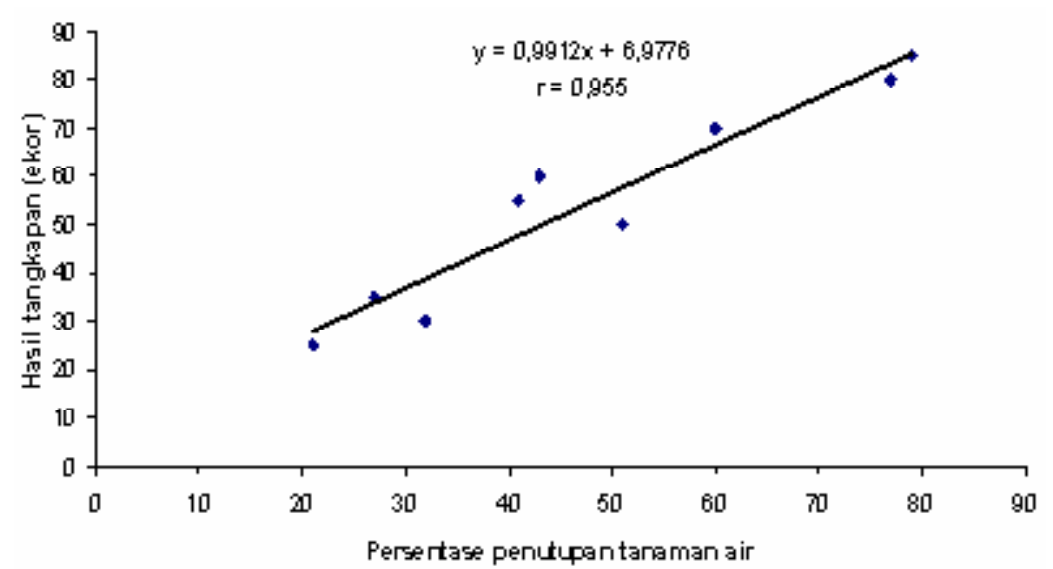

Gambar 3. Hubungan kerapatan tanaman air dengan jumlah ikan betok ( . testudineus) yang tertangkap di masing-masing habitat.

Figure 3. Relationship of aquatic plant density and number of climbing perch (A. testudineus) caught in each habitat. 


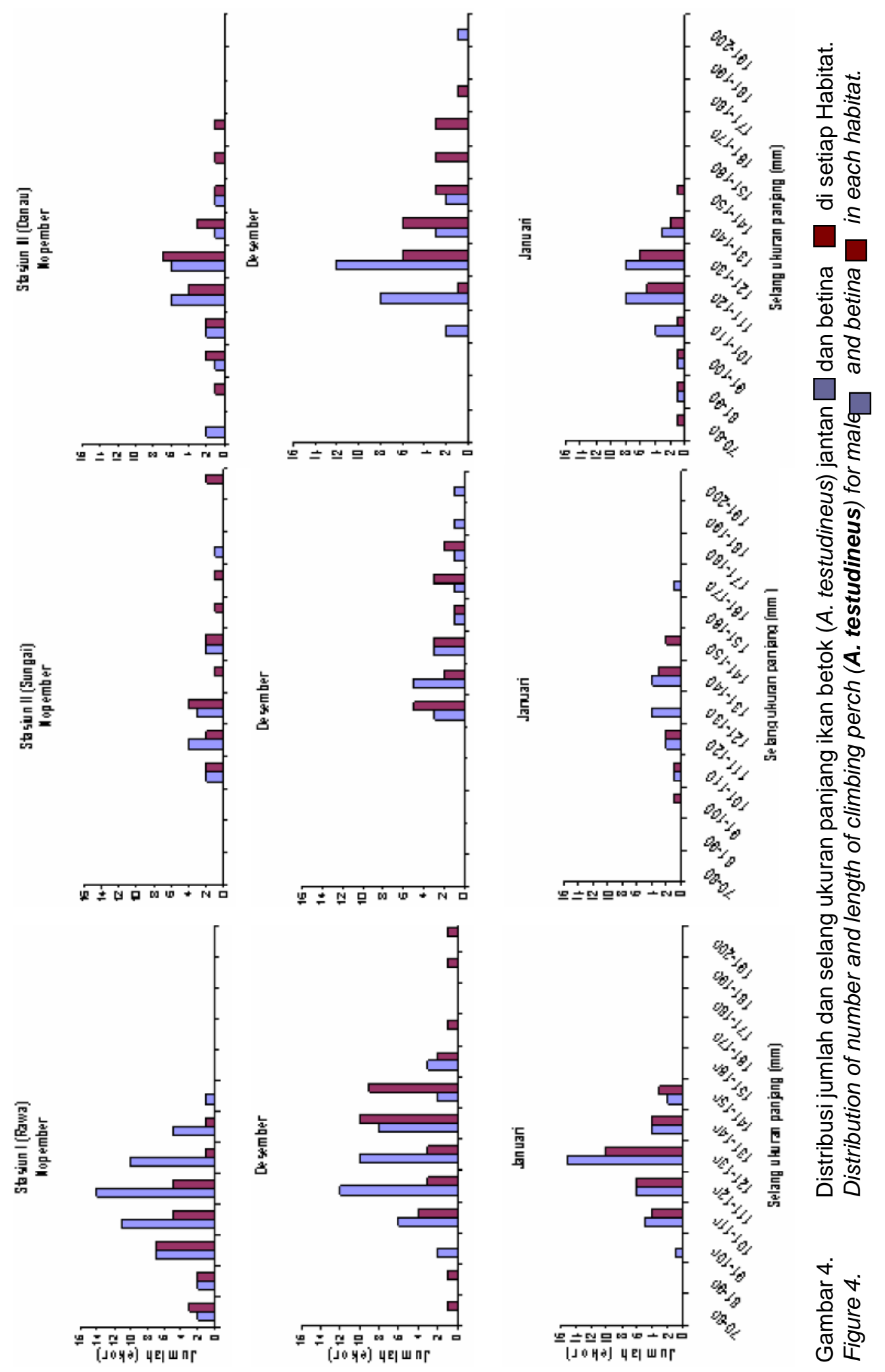


Distribusi jumlah dan selang ukuran panjang ikan betok jantan dan betina menurut waktu sampling dan habitat selama penelitian dapat dilihat pada Gambar 4. Kelas ukuran panjang ikan jantan dan betina selama penelitian masing-masing berkisar 72-195 dan 71-196 $\mathrm{mm}$. Secara umum, distribusi selang ukuran panjang ikan jantan dan betina terlihat cukup seimbang, akan tetapi sebaran setiap bulannya terlihat adanya pegeseran dominasi pada selang ukuran panjang tertentu.

Di habitat rawa, pada bulan Nopember dominasi selang ukuran panjang ikan betok berkisar $91-130 \mathrm{~mm}$ untuk jantan dan 91-120 mm untuk betina. Pada bulan Desember, dominasi ukuran panjang ikan jantan adalah relatif stabil dan ikan betina cenderung bergeser relatif mencolok dan lebih besar dari bulan sebelumnya, yaitu 131-150 mm. Selanjutnya pada bulan Januari, kisaran ukuran ikan jantan maupun betina cenderung mengecil $(111-130 \mathrm{~mm})$.

Di habitat sungai, pada bulan Nopember, panjang ikan jantan dan betina masing-masing didominasi oleh kisaran 111-130 dan 121-130 mm. Pada bulan Desember, sebagian besar hasil tangkapan ikan jantan berukuran 121-150 mm, sedangkan ukuran ikan betina cenderung berfluktuasi yang didominasi oleh 121-130 $\mathrm{mm}$. Pada bulan Januari, ikan yang diperoleh relatif sedikit yang mana dominasi ukurannya lebih rendah dibandingkan hasil tangkapan di bulan Desember terutama ikan betina.

Pada bulan November, distribusi ukuran panjang ikan yang diperoleh di habitat danau mempunyai pola pergeseran selang ukuran yang mirip dengan habitat rawa dan sungai, yaitu $110-130 \mathrm{~mm}$. Pada bulan Desember, panjang ikan betok didominasi oleh 110 $140 \mathrm{~mm}$ untuk jantan dan 121-170 mm untuk betina. Pada bulan Januari, ukuran ikan jantan dan betina berkisar 111-130 mm.

Secara keseluruhan, di setiap habitat terlihat adanya pola distribusi selang ukuran panjang terbesar yang terjadi pada bulan Desember. Ada dua kelompok selang ukuran panjang terbanyak di habitat sungai yaitu, 110-130 mm dan 131-150 mm. Kelimpahan ikan pada ukuran yang berbeda dikarenakan oleh awal musim pemijahannya yang berbeda pada setiap habitat, sehingga ikan dari hasil pemijahan yang lebih dulu, selanjutnya pada waktu yang sama ditemukan dalam ukuran yang lebih besar. Pola sebaran ukuran ikan betok pada penelitian ini mirip dengan ikan payangka (Ophiocara porocephala) (Satria \& Kartamihardja, 2002) dan jenis-jenis ikan pada umumnya di daerah tropis yang memijah 2 - 3 kali selama musim pemijahan.

Menurut sebaran ukuran panjang ikan betok di setiap habitat, selang ukuran 111-130 mm baik ikan jantan maupun dan betina merupakan hasil tangkapan terbesar jumlahnya. Semakin panjang selang ukuran ikan yang ditemukan, semakin berkurang jumlahnya. Kondisi demikian cenderung seragam. Sedikitnya ukuran terbesar menandakan bahwa populasi ikan betok mulai tertekan. Secara umum, selang ukuran panjang maksimum 190-200 mm di setiap habitat relatif sedikit. Sementara ukuran panjang maksimum ikan betok sebesar $250 \mathrm{~mm}$ (www. Fishbase, 2008) tidak ditemukan selama penelitian. Artinya bahwa sumber daya ikan betok di lingkungan Danau Melintang diduga sudah mengalami tangkap lebih (over exploitation).

\section{Hubungan Panjang Total dan Bobot ikan}

Hubungan panjang dan bobot ikan betok di setiap habitat selama penelitian dapat pada Tabel 1. Sedangkan Tabel 2 memuat hasil uji t terhadap nilai b hubungan panjang berat ikan di setiap habitat. Tingginya nilai koefisien korelasi pada penelitian ini (lebih besar dari 0.82 menunjukkan bahwa relatif kecilnya keragaman yang dipengaruhi oleh faktor lain dan tingginya keeratan hubungan panjang total dan bobot ikan.

Berdasarkan atas nilai koefisien pertumbuhan (b), pertumbuhan ikan betok di habitat rawa mempunyai pola isometrik (nilai b sekitar 3) untuk ikan jantan dan alometrik (nilai b lebih kecil dari 3) untuk ikan betina. Pola pertumbuhan alometrik juga ditemukan pada ikan betok jantan dan betina di habitat sungai dan danau. Secara umum, nilai b berkisar 2,5-4,0, namun kebanyakan mendekati nilai 3 (Lagler et al., 1977 dalam Sulistiono et al., 2001).

Pola pertumbuhan yang berbeda antar habitat dan jenis kelamin diduga berkaitan dengan kondisi lingkungan (waktu penangkapan), perbedaan umur, sediaan makanan, perkembangan gonad, penyakit dan tekanan parasit (Turkmen et al., 2002;). Soumakil (1996) menambahkan, adanya perbedaan pola pertumbuhan pada ikan, kemungkinan karena perbedaan tingkat kematangan gonad, musim, dan kesuburan perairan. Sebagian besar pola pertumbuhan ikan betok yang diperoleh selama penelitian di lingkungan Danau Melintang bersifat alometrik. Hasil ini tidak jauh berbeda dengan hasil pengamatan pertumbuhan ikan betok di Danau Arang-Arang, Jambi (Samuel et al., 2002). 
Tabel 1. Hubungan panjang dan bobot ikan betok (A. testudineus) di setiap habitat Table 1. Relationship of length and weight of climbing perch (A. testudineus) in each habitat

\begin{tabular}{lcccccccc}
\hline \multirow{2}{*}{$\begin{array}{c}\text { Habitat/ } \\
\text { Habitats }\end{array}$} & \multicolumn{4}{c}{ Jantan/Male } & $\begin{array}{c}\text { Jumlah/ } \\
\text { Number }\end{array}$ & b & $\mathbf{R}^{\mathbf{2}}$ & \multicolumn{2}{c}{$\begin{array}{c}\text { Pola Pertumbuhan/ Jumlah/ } \\
\text { Growth pattern }\end{array}$} & Number & b & $\mathbf{R}^{2}$ & $\begin{array}{c}\text { Pola Pertumbuhan/ } \\
\text { Growth pattern }\end{array}$ \\
\hline Rawa & 128 & 3.01 & 0.93 & Isometrik & 88 & 2.77 & 0.94 & Alometrik \\
Sungai & 40 & 2.48 & 0.82 & Alometrik & 40 & 2.97 & 0.88 & Alometrik \\
Danau & 72 & 2.73 & 0.91 & Alometrik & 63 & 2.87 & 0.97 & Alometrik \\
\hline
\end{tabular}

Tabel2.

Table 2.

Uji t nilai koefisien b hubungan panjang berat ikan betok ( $A$. testudineus) di setiap habitat

\begin{tabular}{lccccc}
\multicolumn{1}{c}{ habitat / Habitat } & $\mathbf{B}$ & $\mathbf{d b}$ & $\mathbf{t}_{\text {hit }}$ & $\mathbf{t}_{\text {tab }}(\mathbf{0 , 0 5})$ & $\begin{array}{c}\text { Kesimpulan / } \\
\text { Conclusion }\end{array}$ \\
\hline Rawa & 3,01 & 126 & 1,33 & 1,645 & tn \\
Jantan & 2,78 & 86 & 2,09 & 1,645 & $*$ \\
Betina & & & & & $*$ \\
Sungai & 2,49 & 38 & 2,47 & 1,645 & $*$ \\
Jantan & 2,98 & 38 & 4,88 & 1,645 & \\
Betina & & & & & $*$ \\
Danau & 2,74 & 70 & 4,33 & 1,645 & $*$ \\
Jantan & 2,87 & 61 & 7,75 & 1,645 & $*$ \\
Betina & & &
\end{tabular}

Keterangan: tn = tidak berbeda nyata, ${ }^{*}=$ beda nyata, ${ }^{* *}=$ sangat berbeda nyata

Remarks: $t n=$ no significant difference; ${ }^{*}=$ significant difference, ${ }^{* *}=$ veri significant difference

Habitat rawa yang banyak ditemui vegetasi dan seresah menyediakan makanan bagi ikan betok dibandingkan di sungai dan danau. Perbedaan pola pertumbuhan ikan jantan dan betina di habitat rawa diduga berkaitan dengan perbedaan ukuran ikan yang tertangkap yang mana ikan jantan berukuran relatif lebih kecil dan masih muda dibandingkan betina. Ikan jantan masih dalam fase pertumbuhan. Enerji makanan diduga lebih banyak digunakan untuk pertumbuhan gonad daripada daging pada ikan betina.

\section{Dugaan Laju Pertumbuhan}

Hasil analisis pertumbuhan ( $\mathrm{K}$ dan $\mathrm{L}_{\text {.) }}$ ) dengan Metode ELEFAN 1 menunjukkan bahwa koefisien pertumbuhan dan dugaan panjang asimtotik ikan betok di habitat rawa, sungai, dan danau secara berurutan adalah 0,73/tahun dan $214,20 \mathrm{~mm}, 0,66$ / tahun dan 204,23 mm, serta 1,30/tahun dan 200,55.

Gambar 5 menunjukkan bahwa ada kecenderungan pertumbuhan yang meningkat pesat pada umur antara 1-2 tahun, terutama di habitat danau, rawa, dan terakhir sungai. Nilai $t_{0}$ ikan betok yang peroleh dari hasil perhitungan persamaan Pauly cukup variatif di setiap habitat, di habitat rawa sebesar $-0,13$ tahun, sungai $-0,14$ tahun dan $-0,072$ tahun diperoleh di danau. Dari hasil perhitungan dugaan pertumbuhan panjang $\left(\mathrm{K}, \mathrm{L}\right.$, dan $\left.\mathrm{t}_{0}\right)$ didapat persamaan pertumbuhan panjang ikan betok di berbagai habitat, yaitu: rawa $L_{t}=214,2\left(1-e^{-0,73(t+0,13)}\right)$, sungai $L_{t}=204,23$ $\left(1-e^{-0,66(t+0,14)}\right)$, dan danau $L_{t}=200,55\left(1-e^{-1,3(t+0,072)}\right)$.

Persamaan pertumbuhan Von Bertalanffy yang ditampilkan dalam bentuk kurva pertumbuhan ikan betok di setiap habitat mencapai ukuran panjang maksimum yang berbeda-beda, yaitu $L_{n}=214,20$ untuk rawa, $L_{n}=204,23$ untuk sungai, dan $L_{n}=200,55$ untuk danau. Bila dihubungkan dengan hasil tangkapan di atas yang sebagian besar berukuran 111-130 mm, diduga umurnya berkisar antara 1-2 tahun. Berdasarkan nilai koefisien pertumbuhan $(K)$, ikan betok yang berada di habitat danau lebih cepat mencapai panjang asimtotik. Peningkatan nilai $\mathrm{K}$ menunjukkan peningkatan kecepatan ikan mencapai panjang asimtotik sehingga ikan yang memiliki nilai $\mathrm{K}$ lebih besar umumnya memiliki siklus hidup yang lebih singkat (Harahap \& Djamali, 2005).

Nilai $\mathrm{K}$ juga menunjukkan adanya perbedaan di habitat rawa, sungai, dan Danau. Di habitat danau, nilai $\mathrm{K}$ relatif lebih tinggi dibandingkan habitat lainnya. Hal ini diduga terkait dengan kondisi perairan danau yang relatif lebih baik dibandingkan rawa dan sungai. Pada kondisi perairan lebih baik seperti makanan, suhu, dan kondisi perairan, pertumbuhan ikan akan 


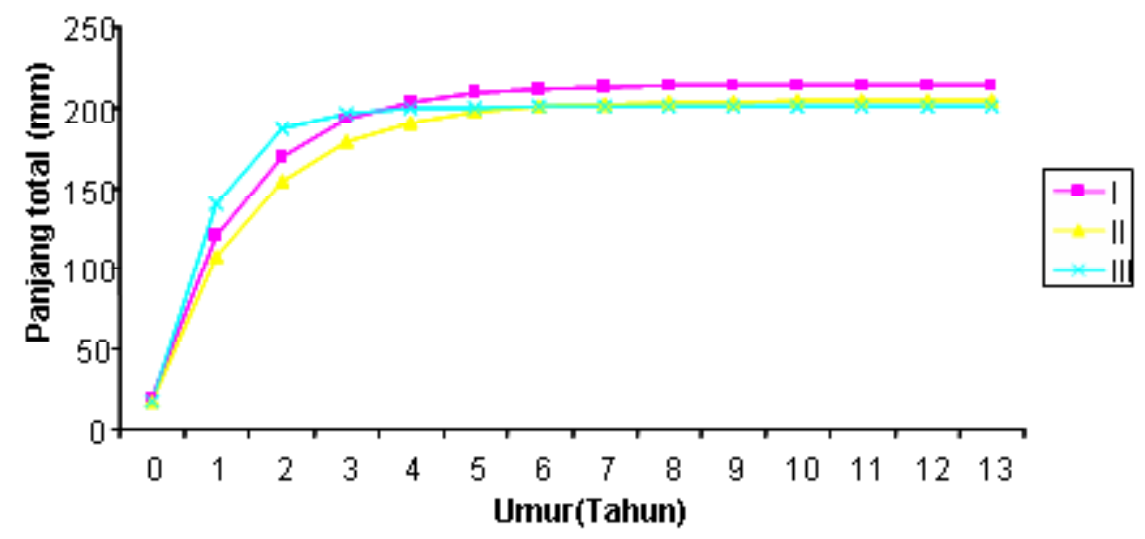

Gambar 5. Pertumbuhan panjang ikan betok (A. testudineus) di setiap Habitat (I: rawa, II: sungai, III: danau).

Figure 5. Growth of length of climbing perch (A. testudineus) in each habitat (I: flood plains, II: river, III: lake).

mencapai optimum (Weatherley, 1972). Selain faktor lingkungan, kelimpahan makanan yang cukup besar diduga mendorong laju pertumbuhan (Sulistiono et al., 2001).

\section{KESIMPULAN}

1. Distribusi hasil tangkapan ikan betok $(A$. testudineus) terbanyak ditemukan di rawa, kemudian diikuti oleh danau dan sungai. Komposisi hasil tangkapan didominasi selang ukuran $110-130 \mathrm{~mm}$.

2. Pola pertumbuhan ikan betok jantan dan betina di rawa masing-masing adalah isometrik dan alometrik. Di sungai dan danau, pola pertumbuhan ikan jantan dan betina adalah alometrik.

3. Berdasarkan atas dugaan parameter pertumbuhan Von Bertalanffy, nilai $\mathrm{K}$ dan $\mathrm{L}$, masing-masing adalah $0,73 /$ th dan $214,2 \mathrm{~mm}$ untuk rawa, $0,66 /$ th dan $204,23 \mathrm{~mm}$ untuk sungai, dan 1,30 th dan $200,55 \mathrm{~mm}$ untuk danau. Habitat danau merupakan habitat dengan nilai $\mathrm{K}$ tertinggi dibandingkan yang lainnya.

\section{PERSANTUNAN}

Tulisan ini bagian dari kegiatan penelitian yang berjudul Kebiasaan Makanan, Pertumbuhan dan Reproduksi Ikan Betok (Anabas testudineus) di Lingkungan Danau Melintang, Kalimantan Timur yang dibiayai swadana pada tahun 2007.

\section{DAFTAR PUSTAKA}

Effendie, M. I. 1979. Metode Biologi Perikanan. Yayasan Dewi Sri. Bogor. 112 pp.

Harahap, T. S. R. \& A. Djamali. 2005. Pertumbuhan ikan terbang (Hirundichthys oxycephalus) di perairan Binuangeun Banten. Jurnal Iktiologi Indonesia. 5 (2): 49-54.

Krebs, C. J. 1985. Ecology: The Experimental Analysis of Distribution and Abudance. Third Edition. Harper Collin Publisher. New York.

Nasution, S. H. 2000. Ikan Hias Air Tawar Rainbow. Cetakan I. Penebar Swadaya. Jakarta. 96 pp.

Pollnac, R. B. \& S. P. Malvestuto. 1992. Biological and sosio economic conditions for the development and management of riverine fisheries resources oin the Kapuas and Musi Rivers. 24-37 p. In Pollnac R. B., C. Baeiley, \& A. Purnomo. 1992. Contribution to Fishery Development Policy in Indonesia. Central Research and Development for Fisheries. Agency for Agricultural Research and Development. Ministry of Agriculture. Jakarta.

Penzcak, T. 1995. Effect of remofal and bankside vegetation on fish population dynamics in the Warta River, Poland. Hydrobiologia. 303: 207-210.

Soumokil, A. 1996. Telah beberapa parameter populasi ikan momar putih (Decapterus ruselii) di perairan 
Kecamatan Amahai, Maluku Tengah dan alternatif pengelolaannya. Tesis. Program Pascasarjana. Institut Pertanian Bogor.

Sparre, P. \& S. C. Venema. 1999. Introduksi Pengkajian Stok Ikan Tropis. Buku 1: Manual. Pusat Penelitian dan Pengembangan Perikanan, penerjemah. Jakarta. Pusat Penelitian dan Pengembangan Perikanan.

Sulistiono, R. Arwani \& K. A. Azis. 2001. Pertumbuhan ikan belanak (Mugil dussumierı) di perairan Ujung Pangkah Jawa Timur. Jurnal Ikhtiologi Indonesia. $1(2): 39-47$.

Satria, H. \& E. S. Kartamihardja. 2002. Distribusi panjang total dan kebiasaan makan yuwana ikan payangka (Ophiocara porocephala). Jurnal Penelitian Perikanan Indonesia. 8 (1): 41-50.

Samuel, S. Adjie, \& Z. Nasution. 2002. Aspek lingkungan dan biologi ikan di Danau Arang-Arang,
Propinsi Jambi. Jurnal Penelitian Perikanan Indonesia. 8 (1): 1-13.

Turkmen, M., O. Erdogan, A. Yildirim, \& I. Akyurt. 2002. Reproductive tactics, age, and growth of Capoeta capoeta umbla Heckel 1834 from the Askale Region of the Karsu Rivers. Turkey. Fisheries Research. 54: 317-328.

Utomo, A. D. 2002. Pertumbuhan dan biologi reproduksi udang galah (Macrobrachium rosenbergii) di Sungai Lempuing Sumatera Selatan. Jurnal Penelitian Perikanan Indonesia. $8(1): 15-26$.

Weatherley, L. A. 1972. Growth and Ecology of Fish Population. Academic Press. Inc. London. 293 pp.

Welcomme, R. L. 1985. River Fisheries. FAO. Fisheries Technical Paper. 